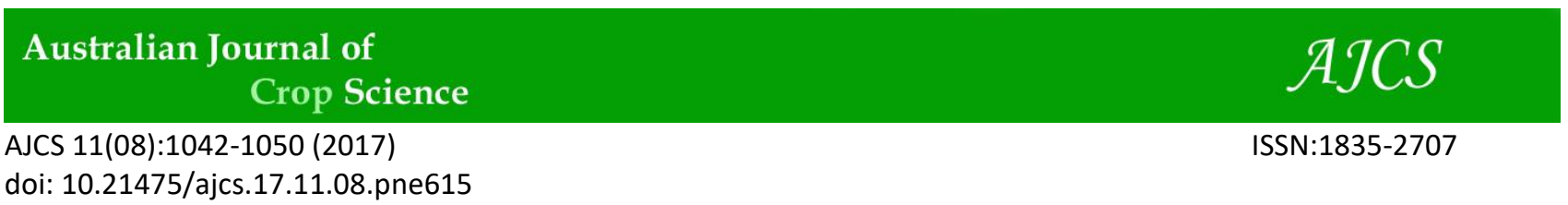

\title{
Diversity and indicator species in the cerrado biome, Brazil
}

\author{
Fernanda Gomes Ferreira ${ }^{1} *$, Evandro Luiz Mendonça Machado ${ }^{2}$, Carlos de Melo e Silva-Neto ${ }^{3}$, \\ Manoel Cláudio Silva Júnior ${ }^{4}$, Mariana Martins Medeiros ${ }^{5}$, Anne Priscila Dias Gonzaga ${ }^{6}$, Alexandro \\ Solórzano $^{7}$, Fábio Venturoli ${ }^{1}$, Jeanine Maria Felfili Fagg ${ }^{4,8}$
}

${ }^{1}$ Department of Forest Engineering, School of Agronomy, Federal University of Goiás (UFG), Goiânia, Brazil ${ }^{2}$ Department of Forest Engineering, Federal University of the Jequitinhonha and Mucuri Valleys (UFVJM), Diamantina, Brazil

${ }^{3}$ Federal Institute of Education, Science and Technology of Goiás (IFG), Cidade de Goiás, Brazil

${ }^{4}$ Department of Forest Engineering, College of Technology, University of Brasília (UNB), Brasília, Brazil

${ }^{5}$ Department of Forest Engineering, Amapá State University (UEAP), Macapá, Brazil

${ }^{6}$ Interdisciplinary College of Humanities, Federal University of the Jequitinhonha and Mucuri Valleys (UFVJM), Diamantina, Brazil

${ }^{7}$ Department of Geography and Environment, Pontifical Catholic University of Rio de Janeiro (PUC), Rio de Janeiro, Brazil

${ }^{8}$ In memorian.

*Corresponding author: gomesfernanda@hotmail.com

\begin{abstract}
The Cerrado biome has high species richness, endemism and spatial heterogeneity. Knowing the main characteristics and peculiarities of the flora is essential to adequately protect the species richness of the Cerrado. Therefore, the objective of this study was to analyze the species richness, alpha diversity and beta diversity of four vegetation types in the Paracatu River Basin $\left(15^{\circ} 30^{\prime} / 19^{\circ} 30^{\prime} \mathrm{S}\right.$ and $\left.45^{\circ} 10^{\prime} / 47^{\circ} 30^{\prime} \mathrm{W}\right)$, Paracatu-MG. The four vegetation types cerrado (stricto sensu, "cerradão" or Savannah woodland, deciduous seasonal forest and riparian forest) were sampled following the Manual for Monitoring Permanent Plots of the Cerrado and Pantanal Biomes. Alpha diversity was assessed using the Simpson (Ds') and Shannon \& Wiener (H') indexes, and beta diversity using the Sørensen and Jaccard similarity indexes. The "cerradão" vegetation type had the highest number of species (106) and highest alpha diversity (3.83nats.ind ${ }^{-1}$ ). The cerrado stricto sensu had the lowest species richness (54 species) and alpha diversity value (2.65 nats. ind $\left.{ }^{-1}\right)$. Beta diversity was high (low Jaccard and Sørensen similarity) except between cerrado stricto sensu and "cerradão". The initial hypothesis of this study was rejected, because although the phytophysiognomies are located on the same land system, the beta diversity is high, except for the cerrado stricto sensu and "cerradão", which had similar diversity.
\end{abstract}

Keywords: alpha and beta diversity, "cerrado stricto sensu”, "cerradão", deciduous forest, riparian forest.

Introduction

The Cerrado biome has high species richness, endemism, spatial heterogeneity (Machado et al., 2008) and is currently considered the most species rich Savannah in the world (Myers et al., 2000), with more than 11 thousand species of vascular plants (Mendonça et al., 2008). Species richness is linked to the different vegetation types, which range from grasslands to forests (Machado et al., 2004). Knowing the main characteristics and the environmental integrity of the flora is essential to adequately plan and carry out the conservation of the Cerrado Biome. Biological characteristics and environmental integrity may be estimated using diversity indexes as well as by comparing areas. Alpha diversity indexes are based on the proportion of species abundance and are the most used in ecology, although species abundance models describe diversity more fully. Therefore, both uniformity (measured as equitability) and species richness are considered (Barros, 2007).

Alpha diversity values enable the comparison of different communities in regards to diversity and richness. However, similarity of species composition is disregarded. Beta diversity is used as an environmental heterogeneity measure so that regions with low pairwise similarity have high beta diversity. Beta diversity is also assessed comparing species composition among different communities (Magurran, 2004). Studies evaluating beta diversity for the Cerrado region are few and punctual (Felfili et al., 2004; Ferreira, 2006; Haidar et al., 2013). In tropical regions, similar studies focus on rainforests (Condit et al., 2002; Tuomisto et al., 2003; Davidar et al., 2007; Arroyo-Rodríguez et al., 2013).

The species distribution in the Cerrado is correlated to edaphic characteristics, primarily chemical characteristics such as natural fertility (Martins et al., 2016). Cochrane et al., (1985), reported 25 physiographic regions and 70 different land systems in Central Brazil with recurrent climate, landscape and soil patterns. The sites studied are located within the same land system, so species overlap is believed to be high among the vegetation types. Therefore, the hypothesis of this study was that, the overlap in plant species 
in basins located on the same land system is high, hence the low beta diversity in the region. The objective of this study was to analyze species richness and the alpha and beta diversities of the four vegetation types in the Paracatu River Basin (Paracatu-MG) and to perform a species indicator analysis for each of the studied vegetation types.

\section{Results and Discussion}

\section{Richness and Alfa diversity}

The Cerradão had 106 plant species, 1.376 ind.ha $^{-1}$, a basal area of $24.22 \mathrm{~m}^{2} \cdot \mathrm{ha}^{-1}$, and the highest species richness, density and basal area, followed by the deciduous forest, riparian forest and Cerrado stricto sensu (Table 1). The smallest trees, associated with Cerrado stricto sensu (savanna formation), had lower basal areas. The cerradão was sampled with a different inclusion criteria from that used for other forest formations, which promoted the greater density and basal area values.

The riparian forest had the lowest density $\left(560\right.$ ind.ha $\left.^{-1}\right)$ in this study and in studies carried out in other areas, for example, 723 ind.ha $^{-1}$ in riparian forest of Carinhanha River basin (state of Bahia, Brazil; Gomes et al., 2014), 2.306 ind.ha ${ }^{-1}$ in the Taquari-Antas River basin (state of Rio Grande do Sul, Brazil; Teixeira et al., 2014), 3.788 ind.ha $^{-1}$ in gallery forests of Acampamento (Distrito Federal, Brazil; Guarino and Walter, 2005), 3445 ind ha ${ }^{-1}$ in the riparian forest of the Gurguéia River (state of Piauí, Brazil; Silva et al., 2015), and 1.475 ind.ha $^{-1}$ in flooding areas of the Canjerana Park (Distrito Federal, Brazil; Dietzsch et al., 2006). The low plant density observed in the riparian forest evaluated is apparently related to annual perturbations, such as natural floods that soak the soil increase superficial runoff, carrying organic matter, seeds, and seedlings and saplings of local species into the waterbody. Cattle from within the studied fragments trample younger individuals (e.g., plant saplings) hindering the development of most plants. Cattle trampling leads to a reduction in the number of individuals that will make up the canopy layer of the riparian forest.

A high number of rare species was recorded in all vegetation types. Rare species tend to occur in higher frequencies in tropical forests (Hartshorn, 1980; ter Steege et al., 2013), where ecological dominance is common (Odum, 2004). Approximately $1 / 4-1 / 3$ of the tropical species are sampled in low densities (Hartshon, 1980). In addition, most phytosociological studies have reported few species contributing to the total density (percent contribution) in different savanna or tropical forest formations (Felfili et al., 2007; Pinto et al., 2007; Medeiros and Walter, 2012; Giácomo et al., 2013).

Ecological dominance occurs mostly in sites with extremely high or low resource availability in tropical environments (Ashton, 1990). Overall, few species adjust to extreme conditions, such as flooding events in the Cerrado stricto sensu and in the riparian forest. Such extreme conditions provide optimal colonization opportunities for better-adapted species, given the low interspecific competition. This explains the high dominance of Curatella americana and Byrsonima crassifolia in cerrado stricto sensu on Fluvisol (Ferreira et al., 2010), and the dominance of Acacia polyphylla in the riparian forest of the Paracatu River (Medeiros, in press).

The deciduous forest had a higher number and proportion of rare species in regards to total richness. However, some species rare in the deciduous forest are sampled in higher densities in other vegetation types (e.g., cerrado stricto sensu), namely Curatella americana, Dimorphandra mollis, Eugenia dysenterica, Leptolobium dasycarpum, Magonia pubescens and Tabebuia aurea (Ratter et al., 2003; Bridgewater et al., 2004). Therefore, the surrounding vegetation (in this case the cerrado stricto sensu) influences the floristic composition of the deciduous forest analyzed.

Many of the species collected in the cerrado stricto sensu were rare species. Most of these rare species (e.g., Alibertia edulis, Bowdichia virgilioides, Callisthene fasciculata, Myrcia rostrata, Qualea grandiflora and Siparuna guianensis) are abundant in other areas of the Cerrado stricto sensu, where the soil has good drainage conditions (Balduino et al., 2005; Saporetti Júnior et al., 2003; Fonseca and Silva Júnior, 2004; Teixeira et al., 2004; Neri et al., 2007; Finger and Finger, 2015). The anoxia caused by the flooding period may, in a way, restrict the establishment of larger populations of species usually more abundant in other areas where the soils have a good drainage.

The floristic composition recorded in the Paracatu River basin are within the limits detected in other sites for the riparian forest and cerradão (Carvalho et al., 1996, PereiraSilva et al., 2004, Barttilani et al., 2005, Lacerda et al., 2005 e, Souza et al., 2008). However, the Cerrado stricto sensu had the $3^{\text {rd }}$ smallest floristic richness when compared with the other 29 areas in Central Brazil (Ferreira et al., 2010) and the smallest among the four vegetation types studied.

The deciduous seasonal forest showed high richness when compared with other areas in other regions of the country (Santos et al., 2007; Bianchin and Bellé, 2013). The studied deciduous forest has many species typical of the Cerrado stricto sensu vegetation type. Therefore, many species were included in the deciduous forest sampling, leading to a high diversity when compared to other deciduous seasonal forests. The low species richness (54) observed for the Cerrado stricto sensu may be associated with the environmental control carried out by anoxia. Few species are able to survive anoxia. Therefore, it limits the number of species able to become established in the environment. However, the estimates made by the first and second order jackknife were high, indicating that the area has an increasing potential for richness (Fig 1).

The riparian forest sample best approached the asymptote. The other areas showed a tendency of having a larger number of species, due to the high number of rare species. The Shannon and Wiener $\left(H^{\prime}\right)$, and Simpson $\left(D s^{\prime}\right)$ diversity indexes and Pielou's evenness $\left(J^{\prime}\right)$ quantified local biodiversity and reflected community structures in regards to the relative abundance of the different species that make up richness of the different vegetation types.

Overall, the high alpha diversity reported for the cerradão, riparian forest and deciduous forest vegetation types, indicated some heterogeneity and a lower ecological dominance. The Cerrado stricto sensu had low diversity and evenness values which indicate high ecological dominance. The species Curatella americana contributed to near $33.6 \%$ of all individuals. This result may be partially explained by the anoxia condition observed especially in the rainy season, caused by the poor soil drainage conditions.

\section{Beta diversity}

Beta diversity among the sampled vegetation types was overall high (Table 2 - B) as the Jaccard and Sørensen indexes indicated low floristic and structural similarity among the vegetation types, except when Cerrado stricto sensu was compared with cerradão. 
Table 1. Structure, floristic richness and alpha diversity for four vegetation types sampled in the Paracatu River basin, MG.

\begin{tabular}{|c|c|c|c|c|}
\hline & \multicolumn{4}{|c|}{ Plant types } \\
\hline & Cerrado stricto sensu & Riparian forest & cerradão & Deciduous forest \\
\hline \multicolumn{5}{|l|}{ Sampling: } \\
\hline Number of plots (N) & $10(20 \times 50)$ & $100(10 \times 10)$ & $10(20 \times 50)$ & $25(20 \times 20)$ \\
\hline Inclusion criterion (IC) & $\mathrm{Bd}_{30} \geq 5 \mathrm{~cm}$ & $\mathrm{DBH} \geq 5 \mathrm{~cm}$ & $\mathrm{Bd}_{\mathrm{b} 30} \geq 5 \mathrm{~cm}$ & $\mathrm{DBH} \geq 5 \mathrm{~cm}$ \\
\hline Number of species $(\mathrm{S})$ & 54 & 56 & 106 & 76 \\
\hline Number of individuals (Ni) ha ${ }^{-1}$ & 697 & 560 & 1376 & 1046 \\
\hline Basal area $(\mathrm{BA}) \mathrm{m}^{2} \cdot \mathrm{ha}^{-1}$ & 6.41 & 20.32 & 24.22 & 21.76 \\
\hline \multicolumn{5}{|l|}{ Rare species: } \\
\hline Number of rare species: & 13 & 10 & 21 & 22 \\
\hline Percentage of rare individuals & 1.87 & 1.79 & 1.60 & 2.01 \\
\hline Percentage of rare species & 24.07 & 17.86 & 20.75 & 27.63 \\
\hline \multicolumn{5}{|l|}{ Species diversity: } \\
\hline Shannon \& Wienner index $\left(H^{\prime}\right)$ & 2.65 & 3.26 & 3.83 & 3.25 \\
\hline Simpson Index $\left(D s^{\prime}\right)$ & 0.84 & 0.93 & 0.96 & 0.92 \\
\hline Pielou evenness $\left(J^{\prime}\right)$ & 0.67 & 0.81 & 0.82 & 0.75 \\
\hline $1^{\text {st }}$ order jackknife estimator & 76.5 & 68.9 & 133.9 & 106.8 \\
\hline $1^{\text {st }}$ order jackknife estimator & 88.0 & 74.8 & 140.0 & 121.8 \\
\hline
\end{tabular}

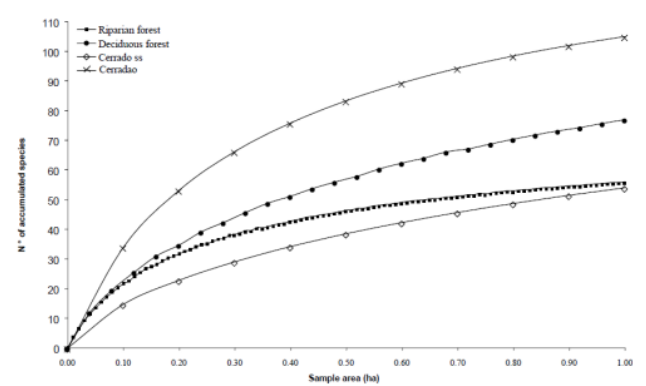

Fig 1. Cumulative number of species per area sampled for four vegetation types in the Middle Paracatu River, MG.

Table 2. (A) Common species; (B) Jaccard similarity index (left side), Sørensen similarity index (right side); (C) Comparison of the Shannon-Wiener diversity indexes using Hutcheson's $t$ test for the four vegetation types sampled in the Paracatu River basin, MG.

\begin{tabular}{|c|c|c|c|c|}
\hline (A) & Cerrado $s s$ & Riparian forest & cerradão & Deciduous forest \\
\hline Cerrado stricto sensu & & - & - & - \\
\hline Riparian forest & 10 & & - & - \\
\hline cerradão & 41 & 10 & & - \\
\hline Deciduous forest & 16 & 14 & 18 & \\
\hline \multicolumn{5}{|l|}{ (B) } \\
\hline Cerrado stricto sensu & - & 18.18 & 51.57 & 24.43 \\
\hline Riparian forest & 10.00 & - & 12.42 & 21.05 \\
\hline cerradão & 34.75 & 6.62 & - & 19.78 \\
\hline Deciduous forest & 13.91 & 11.76 & 10.98 & - \\
\hline \multicolumn{5}{|l|}{ (C) } \\
\hline Cerrado stricto sensu & - & - & - & - \\
\hline Riparian forest & 7.25 & - & - & - \\
\hline cerradão & -16.93 & $-9,69$ & - & - \\
\hline Deciduous forest & -7.67 & 0.11 & 11.14 & - \\
\hline
\end{tabular}

$\mathrm{p} \leq 0.001^{* * *}=$ significant; $\mathrm{ns}=$ non-significan

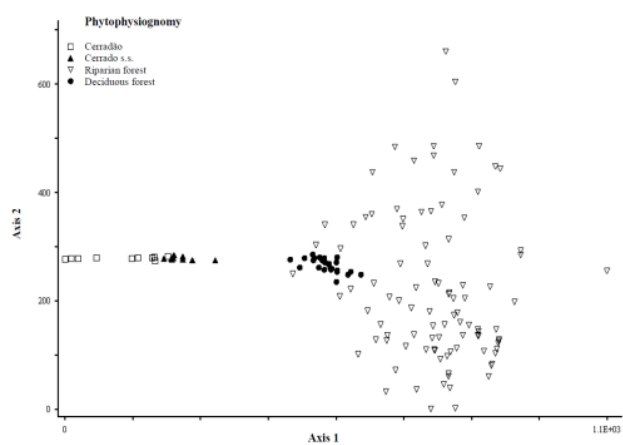

Fig 2. Detrended Correspondence analysis (DCA) for tree density in plots of four vegetation types (Cerrado stricto sensu, cerradão, riparian forest and deciduous seasonal deciduous forest) sampled in the Paracatu River basin, MG. 
Table 3. Indicator Species Analysis with significance level below $0.001 \%(* * * P<0.001)$, of four vegetation types and the respective abundance. OIV= Observed indicator value (\%), EIV = expected indicator value (mean, standard deviation and significance).

\begin{tabular}{|c|c|c|c|c|}
\hline \multirow{2}{*}{$\begin{array}{l}\text { Vegetation type } \\
\text { Species }\end{array}$} & \multirow{2}{*}{ OIV } & \multicolumn{3}{|l|}{ EIV } \\
\hline & & Mean & $\mathrm{SD}$ & $P$ \\
\hline \multicolumn{5}{|l|}{ Cerrado stricto sensu } \\
\hline Byrsonima crassifolia & 99.1 & 8.0 & 4.62 & $* * *$ \\
\hline Curatella americana & 92.1 & 9.4 & 5.01 & $* * *$ \\
\hline Zanthoxylum riedelianum & 88.4 & 7.5 & 4.24 & $* * *$ \\
\hline Eugenia dysenterica & 65.5 & 9.3 & 5.28 & $* * *$ \\
\hline Tachigali aurea & 50.0 & 5.8 & 3.73 & $* * *$ \\
\hline \multicolumn{5}{|l|}{ Riparian forest } \\
\hline Acacia polyphylla & 48.0 & 16.5 & 5.81 & $* *$ \\
\hline \multicolumn{5}{|l|}{ cerradão } \\
\hline Qualea grandiflora & 99.1 & 7.8 & 4.64 & $* * *$ \\
\hline Copaifera langsdorffii & 93.9 & 10.0 & 5.14 & $* * *$ \\
\hline Emmotum nitens & 90.0 & 7.4 & 4.13 & $* * *$ \\
\hline Qualea parviflora & 82.3 & 7.7 & 4.57 & $* * *$ \\
\hline Cordiera macrophylla & 80.0 & 7.0 & 4.08 & $* * *$ \\
\hline Tachigali subvelutina & 80.0 & 6.9 & 3.97 & $* * *$ \\
\hline Simarouba versicolor & 80.0 & 7.1 & 4.41 & $* * *$ \\
\hline Platypodium elegans & 70.0 & 6.7 & 3.97 & $* * *$ \\
\hline Bowdichia virgilioides & 65.9 & 7.0 & 4.36 & $* * *$ \\
\hline Qualea multiflora & 64.6 & 7.4 & 4.51 & $* * *$ \\
\hline Xylopia aromatica & 63.2 & 8.0 & 4.15 & $* * *$ \\
\hline Machaerium acutifolium & 58.3 & 7.4 & 4.6 & $* * *$ \\
\hline Myrcia rostrata & 57.0 & 6.6 & 4.45 & $* * *$ \\
\hline Astronium fraxinifolium & 54.7 & 12.5 & 5.91 & $* * *$ \\
\hline Aspidosperma tomentosum & 50.0 & 5.9 & 3.85 & $* * *$ \\
\hline \multicolumn{5}{|l|}{ Deciduous forest } \\
\hline Aspidosperma pyrifolium & 92.0 & 11.2 & 5.46 & $* * *$ \\
\hline Anadenanthera colubrina & 88.0 & 10.8 & 5.25 & $* * *$ \\
\hline Myracrodruon urundeuva & 73.5 & 14.3 & 6.06 & $* * *$ \\
\hline Handroanthus impetiginosus & 59.7 & 9.3 & 5.07 & $* * *$ \\
\hline Coutarea hexandra & 52.0 & 8.5 & 4.58 & $* * *$ \\
\hline
\end{tabular}

$* * * P<0.001$.

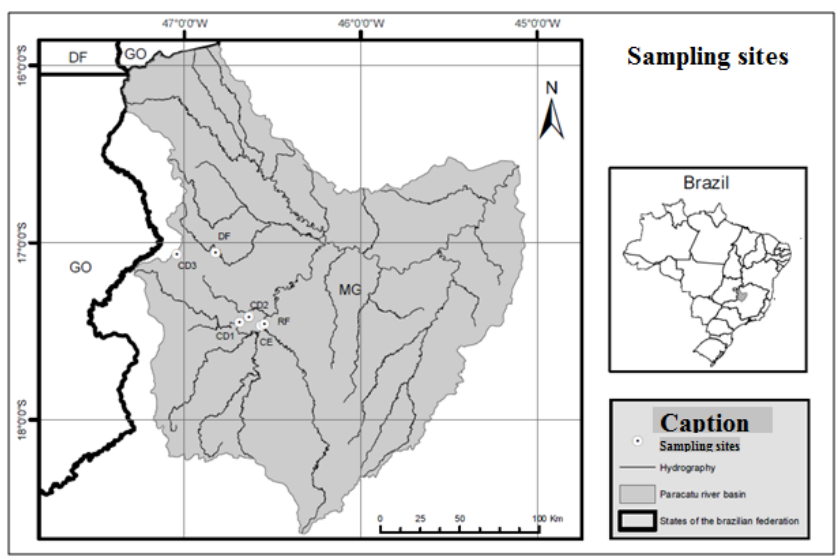

Fig 3. Sampling sites for each vegetation type. CE: Cerrado stricto sensu, RF: riparian forest, CD1, CD2 e CD3: cerradão area and DF: deciduous forest.

Table 4. The geographical and environmental information for the four plant communities sampled in the middle section of Rio Paracatu-MG, Brazil. Areas: Cerrado stricto sensu (CE), cerradão (CD), deciduous forest (DF), riparian forest (RF), soil base saturation (V).

\begin{tabular}{|c|c|c|c|c|c|c|c|}
\hline Areas & $\begin{array}{l}\text { Latitude } \\
(\mathrm{S})\end{array}$ & $\begin{array}{l}\text { Longitude } \\
(\mathrm{W})\end{array}$ & Altitude (m) & Area (ha) & Soil class ${ }^{*}$ & $\begin{array}{l}\mathrm{V} \\
(\%)\end{array}$ & Texture \\
\hline $\mathrm{CE}$ & $17^{\circ} 28^{\prime} 12.43^{\prime \prime}$ & $46^{\circ} 33^{\prime} 51.99^{\prime \prime}$ & 520 & 22.3 & $\mathrm{~F}$ & 14.1 & loam, clay \\
\hline CD1 & $17^{\circ} 27^{\prime} 0.26^{\prime \prime}$ & $46^{\circ} 41^{\prime} 17.03^{\prime \prime}$ & 572 & 45 & $\mathrm{RO}$ & 8 & loam, clay, sand \\
\hline $\mathrm{CD} 2$ & $17^{\circ} 25^{\prime} 3.73^{\prime \prime}$ & $46^{\circ} 37^{\prime} 49.64^{\prime \prime}$ & 564 & 221.6 & RO & 10 & loam, clay, sand \\
\hline CD3 & $17^{\circ} 3^{\prime} 50.01 "$ & $47^{\circ} 2^{\prime} 22.84^{\prime \prime}$ & 950 & 104.5 & RO & 7.3 & loam, clay, sand \\
\hline DF & $17^{\circ} 3^{\prime} 16.6^{\prime \prime}$ & $46^{\circ} 49^{\prime} 23.5^{\prime \prime}$ & 720 & 473 & $\mathrm{~L}$ & - & - \\
\hline $\mathrm{RF}$ & $17^{\circ} 27^{\prime} 31.47^{\prime \prime}$ & $46^{\circ} 32^{\prime} 47.35^{\prime \prime}$ & 525 & 29.3 & & 71 & loam, clay \\
\hline
\end{tabular}

*Soil class prevailing in each vegetation type. F: Fluvisol; LV: Red Oxisol and L: Leptosol. 
The cerradão formation is characterized by species typical of the Cerrado stricto sensu and of the neighboring forest formations, particularly of the semi-deciduous dry and nonflooding gallery forests (Ribeiro and Walter, 2008; Walter et al., 2015). Thus, the physiognomic identity of the cerradão is considered similar to that of forests, however with a different floristic structure once it does not comprise exclusive species. The cerradão and Cerrado stricto sensu formations were more similar to each other in Paracatu (Table 2-A).

The four communities had only five species in common: Astronium fraxinifolium, Casearia sylvestris, Copaifera langsdorffii, Dilodendron bipinnatum and Myracrodruon urundeuva, of which only Astronium fraxinifolium and Casearia sylvestris are indexed in the list of species that are widely distributed in the Cerrado Biome (Ratter et al., 2003). This result shows the uniqueness of the vegetation types studied in the referred river basin and their importance for Cerrado conservation. Felfili et al. (2004), analyzed the similarity between the Pratinha, Veadeiros and São Francisco physiographic units, and identified the Paracatu region as a priority area for conservation. The Paracatu region was identified for having low similarity values with the other sites studied.

Sixteen species occurred in at least three of the four vegetation types. Bridgewater et al. (2004), evaluated beta diversity patterns for the Cerrado in Distrito Federal and recorded 14 species in all 13 areas, while 94 species (of 236) occurred in $50 \%$ or more sites. The Cerrado is indeed very heterogeneous in regards to species composition (see Felfili and Silva junior, 1993 and Ratter et al., 2003).

Areas with high beta diversity values must hold large Conservation Units, to protect most of the regional flora variation (Felfili and Felfili, 2001). The Paracatu river basin has 11 Conservation Units, mostly small Environmental Protection Areas (APAs; Área de Proteção Ambiental) and Private Natural Heritage Reserve (RPPNs; Reserva Particular do Patrimônio Natural) (IGAM, 2006). Small sizes limit the protection potential of these units. Therefore, knowledge on the floristic heterogeneity of Cerrado is very important to subsidize making decisions such as how and where to create conservation units (Felfili and Silva-Júnior, 1993).

The DCA based on population density clearly distinguishes the four communities along environmental gradients. The first ordination axis (eigenvalue $=0.90$ ) arranged the plot into two groups: Cerrado stricto sensu and cerradão, and dry and riparian forests (however more dispersed). The second axis (eigenvalue $=0.62$ ) showed a wide variation among the riparian forest plots (Figure 2). The total variance in the analysis was $18.83 \%$.

The high eigenvalues for the DCA axes 1 and 2 indicate a long gradient of species distribution (eigenvalue $<0.50$ ). This pattern revealed a species preference for a vegetation type.

The DCA has an important feature where the axes are scaled in beta diversity units (Palmer, 2005). In other words, the units or standard deviations for the species are the degree of species input and output along the gradient. Therefore, the analyzing the position of plots on the ordination axes shows the beta diversity of the sampled transects (Kent and Coker, 1992).

The first DCA axis separated the cerradão and Cerrado stricto sensu from the deciduous seasonal forest and the riparian forest. This result confirmed the results of the analysis of similarity between areas where cerradão and Cerrado stricto sensu had the highest species overlap and consequently the lower beta diversity.

The riparian forest was floristically more similar to the deciduous forest. The largest difference among these communities is in the riparian forest association with the watercourse and its structures. The 560 ind.ha $^{-1}$ in the riparian forest reached $20.32 \mathrm{~m}^{2}$.ha ${ }^{-1}$ of basal area, while the 1.046 ind.ha ${ }^{-1}$ in the deciduous forest reached a basal area of only $21.76 \mathrm{~m}^{2} . \mathrm{ha}^{-1}$. The riparian forest had large more spaced trees. The annual flood cycles in the riparian forest restrains the number of species by selecting species resistant to anoxia, and by washing away seeds, saplings and organic matter deposited during the dry season. Species resistant to anoxia must have a refined seed dispersal strategy from the end of the rainy period to the beginning of the dry period, for the germination and initial growth to occur in rates that enable saplings to resist the next flood (Ribeiro and Walter, 2008).

The riparian forest exhibited high variation among plots in the second axis. The riparian forests often have large plant diversity due to the high environmental heterogeneity consequent of topography variations, formation age, soil characteristics and groundwater volume variation (Rodrigues and Leitão Filho, 2000). Such riparian heterogeneity occurs even at a short distance, as for the riparian forest of the Paracatu River, where flooded and dry habitats alternate in the same landscape leading to a large internal variability.

The indicator species analysis revealed 11 indicator species for the Cerrado stricto sensu, one for the riparian forest (Acacia polyphylla), 64 for cerradão and 25 (of which nine were not identified to the species level) for the deciduous forest. Indicator species are species that represent environmental and biological conditions (Rolstad et al., 2002). Table 3 shows the indicator species with significance level lower than $0.001 \%$ (*** $P<0.001)$.

The species Byrsonima crassifolia, Curatella americana, Eugenia dysenterica, Tachigali aurea and Zanthoxylum riedelianum had high observed indicator values (OIV values) in the Cerrado stricto sensu. Curatella americana and Zanthoxylum riedelianum were recorded with high OIVvalues in a fragment of floodplain forest in the municipality of Lagoa da Confusão-TO (Brito, 2005). These two species, along with Tachigali aurea, are considered tolerant to short periods of flooding (Ferreira Júnior, 2009). Such remark concurs with the indication values obtained for the referred species (high OIV), once the periodic flooding does not hinder the establishment of its populations in the flooded Cerrado stricto sensu.

Only the species Acacia polyphylla was considered an indicator (OIV $=48 \%)$ in the riparian forest. Celtis iguanaea and Triplaris gardneriana are considered typical of riparian forests (Walter et al., 2015), occurred in the floristic survey and were not identified as indicators in the analysis. The species Celtis iguanaea was appointed indicator of the deciduous forest in Paracatu, for having the highest abundance and frequencies in deciduous forest plots.

The 64 indicator species of the cerradão represent $60.4 \%$ of the species sampled in this vegetation type. The species Aspidosperma tomentosum, Astronium fraxinifolium, Bowdichia virgilioides, Copaifera langsdorffii, Cordiera macrophylla, Emmotum nitens, Machaerium acutifolium, Myrcia rostrata, Platypodium elegans, Qualea grandiflora, Qualea multiflora, Qualea parviflora, Tachigali subvelutina, Simarouba versicolor and Xylopia aromatica, had high OIV. The species Qualea grandiflora are common to the cerradão and Cerrado stricto sensu, the species Copaifera langsdorffii, Emmotum nitens, Hirtella glandulosa and Siphoneugena densiflora to the dystrophic cerradão, and Callisthene fasciculate and Platypodium elegans to the mesotrophic cerradão (Ribeiro and Walter et al. 2008).

The cerradão had the highest number of indicator species among the studied vegetation types, possibly because it has 
the least adverse conditions for species establishment in flooded environments. Therefore, 34\% of the 64 species considered indicators in the cerradão are typical of the Cerrado stricto sensu, and $13 \%$ of the 64 species, are typical of non-flooded gallery forests (Walter et al., 2015).

The indicator species analysis highlighted 25 indicator species for the deciduous forest, of which nine were unidentified taxa. Apart from the nine unidentified species, the ones with the highest OIV values were: Anadenanthera colubrina, Aspidosperma pyrifolium, Coutarea hexandra, Myracrodruon urundeuva and Handroanthus impetiginosus, all commonly found in the seasonal forests of the Cerrado and Pantanal domains and in the arboreal Caatinga (Carvalho, 2009). The afore mentioned species indicate mesotrophic soils (Carvalho et al., 2005), and are thus indicators of the deciduous seasonal forest.

\section{Materials and Methods}

\section{Study site}

The region studied is located in the middle section of the Paracatu River basin, sub-basin of the São Francisco River (17²8'12.43"; 46³3'51.99')' The Paracatu River is one of the largest and most important tributaries of the São Francisco River. The climate in this region is megathermic rainy, type AW (Köppen, 1936). It is a typical rainy tropical climate with high temperatures and rains from October to April, when $93 \%$ of total annual precipitation is reached. The average precipitation in the river basin is $1.340 \mathrm{~mm}$ and the average annual temperatures range from $21^{\circ}$ to $24^{\circ} \mathrm{C}$ (IGAM, 2006).

The main vegetation types reported within the river basin are Cerrado and Cerrado field (campo Cerrado) (IGAM, 2006). The cerradão are more common in the Southern range of the basin. The grasslands occur mostly on plateau tops and slopes, and the deciduous forests occur in the western portion of the basin. Floodplains occur mainly in valleys of large rivers and palm swamps (veredas) in depressions and valleys surrounding and following headwaters. The Paracatu river basin still has $56.33 \%$ of its natural vegetation cover and $43.08 \%\left(17,701.19 \mathrm{~km}^{2}\right)$ of its remaining area is used for pasture, agriculture and reforestation purposes (IGAM, 2006).

\section{Sampling and description of the sampling areas}

This study comprises four vegetation types: Cerrado stricto sensu, "cerradão" (savannah woodland), deciduous seasonal forest and riparian forest. One hectare was sampled in each physiognomy, following the method described in the Manual for Monitoring of Permanent Plots for the Cerrado and Pantanal Biomes (Felfili et al., 2005).

The Cerrado stricto sensu extends for 22.3 ha, and is located on alluvial land surrounding the riparian forest of the Paracatu River. Small Cerrado patches are inserted in a grassland matrix, leading to a local scale mosaic within the alluvial Cerrado. The vegetation is flooded in the rainy season (October - April). Ten $20 \times 50 \mathrm{~m}$ plots $\left(1000 \mathrm{~m}^{2}\right)$ were randomly selected in the patches of Cerrado stricto sensu for sampling. All individuals with $\mathrm{Bd}_{30 \mathrm{~cm}} \geq 5 \mathrm{~cm}$ were measured and the phytosociological parameters of the area are published in Ferreira et al. (2010).

The cerradão was sampled in three segments with 45, 221.6 and 104.5 ha patches, respectively. The cerradão was sampled following the same procedures as for the Cerrado stricto sensu. The floristic composition of the area is described in Solórzano et al. (2012). The deciduous seasonal forest covers an area of 473 ha, includes several Legal Reserves of different properties and is embedded in large chain of mountains, surrounded by rocky outcrops. The selected deciduous forest fragment was separated into three segments, and each segment was divided into bands, perpendicular to the elevation gradient. Each band of $20 \mathrm{~m}$ width was subdivided into $20 \times 20 \mathrm{~m}$ plots ( 25 plots), so bands could be randomly selected. All woody individuals with $\mathrm{DBH} \geq 5$ were measured in the 25 plots that amounted to 1 hectare.

The riparian forest sampled is 23.9 ha large and is located on the left bank of the Paracatu River, $2 \mathrm{~km}$ after converging with the La Plata River. Nine transects 100 meters away from each other and perpendiculars to river were used to sample the riparian forest. Each transect was divided in continuous $10 \mathrm{x} 10 \mathrm{~m}\left(100 \mathrm{~m}^{2}\right)$ plots, with length varying with forest width. All woody individuals in a hectare with DAP $\geq 5 \mathrm{~cm}$ were measured.

Palm trees, lianas and overall non-woody plants were not sampled in either vegetation types. The nomenclature used for the species list followed the Angiosperm Phylogeny Group classification system (APG IV, 2016). The botanical material was identified in the field, by comparison with specimens of the herbaria of the University of Brasilia (Universidade de Brasília; UB) and of the Brazilian Institute of Geography and Statistics (Instituto Brasileiro de Geografia e Estatística; IBGE). The collected material was sent to specialists when necessary. The fertile exsiccates were stored in the UB and IBGE herbaria. Table1 shows the geographical and environmental information for the four vegetation types analyzed, and Figure 1 shows the sampling sites for each vegetation type.

\section{Vegetation analysis}

\section{Richness and Alfa diversity}

The four vegetation types were evaluated in regard to species richness, Simpson's diversity $\left(D s^{\prime}\right)$, Shannon-Wiener diversity $\left(\mathrm{H}^{\prime}\right)$ and Pielou evenness $\left(\mathrm{J}^{\prime}\right)$ (Brower and Zar 1984). Sampling effort curves were plotted using means and 95\% confidence intervals of the cumulative number of species to compare species richness among communities. Accumulation curves were plotted as described in Mccune and Mefford (1999).

First and second order jackknife estimators were also calculated. These estimators determine the maximum species richness reached considering sample heterogeneity (Heltsche and Forrester, 1983; Palmer, 2005). A Hutcheson's t test (Zar, 1996) was used to compare $H^{\prime}$ values obtained for the communities. Therefore, pairwise comparisons of four vegetation types were carried. Species with one specimen per hectare were considered rare (Martins, 1991; Kageyama and Gandara, 1993) for species richness discussions.

Indicator Species

The indicator species analysis (Dufrêne and Legendre, 1997) was used to determine a species habitat preference, in the four communities studied. This method combines species abundance information into groups of sample units, with the frequency in which the species occur within the groups.

The indicator values were obtained for every species of each physiognomic type. Then, a Monte Carlo procedure was applied to assess the difference between the indicator value and chance. This method combines the degree of specificity of a given species to an ecological status, e.g., habitat type and its fidelity within the status (Mcgeoch et al., 2002). 
Therefore, it is possible to obtain indicator values that measure the association between species and vegetation types, and vary from zero (no indication) to 100 (maximum indication). Therefore, species are considered habitat indicators when a Monte Carlo test between the observed indicator value (OIV) and the expected indicator value (EIV) is significant (Dufrêne and Legendre, 1997). The analysis was carried out in the software PC-ORD for Windows version 4.14 (McCune and Mefford, 1999).

\section{Beta diversity}

Beta diversity values comprise differences in species composition and abundance among the fragments, and were obtained analyzing the similarity among communities through the Sørensen (qualitative) and Jaccard (quantitative) indexes (Kent and Coker, 1992; Mueller-Dombois and Ellenberg, 2002). Therefore, higher beta diversities are obtained when the similarity among the vegetation types is the smallest. The analyses were performed in the software CANOCO 4.5 (Ter Braak and Smilauer, 2002).

The Detrended Correspondence Analysis (DCA) was used evaluate the floristic pattern plots in the different vegetation types sampled. The DCA yields an ordination diagram in which the areas are plotted following among-site similarity (Hill and Gauch, 1980).

\section{Conclusion}

The cerradão had the highest species richness and alpha diversity, while the lowest richness and diversity were recorded for the Cerrado stricto sensu. The initial hypothesis of this study was rejected, because although the phytophysiognomies are located on the same land system, the beta diversity is high, except for the Cerrado stricto sensu and cerradão, which had similar diversity. The indicator species analysis highlighted 11 indicator species for the Cerrado stricto sensu, one for the riparian forest (Acacia polyphylla), 64 for the cerradão and 25 (of which nine were not identified in the species level) for the deciduous forest.

\section{Acknowledgments}

The authors wish to acknowledge the University of Brasília (UNB) and the Coordination for the Improvement of Higher Education Personnel (CAPES - Brazil) for their financial support.

\section{References}

APG IV - Angiosperm Phylogeny Group IV (2016). An update of the Angiosperm Phylogeny Group classification for the orders and families of flowering plants: APG IV. Bot J Linn Soc. 181, 1-20.

Arroyo-Rodríguez V, Rös M, Escobar F, Melo FPL, Santos BA, Tabarelli M, Chazdon R (2013) Plant b-diversity in fragmented rain forests: testing floristic homogenization and differentiation hypotheses. J Ecol. 101:1449-1458.

Ashton PS (1990). Species richness in tropical forests. In: Tropical forests - botanical dynamics, speciation and diversity. In: Holm-Nielsen LB, Nielsen IC, Balslev H (eds). Academic Press, London, p. 239-251 (1990).

Balduino APC, Souza AL, Meira Neto JAA, Silva AF, Silva Júnior MC (2005) Fitossociologia e análise comparativa da composição florística do cerrado da flora de ParaopebaMG. R Árvore, 29 (1): 25-34.
Barros RSM (2007) Medidas de diversidade biológica. Programa de Pós-Graduação em Ecologia Aplicada ao Manejo e Conservação de Recursos Naturais -PGECOL. Universidade Federal de Juiz de Fora - UFJF. Juiz de Fora, MG.

Battilani JL, Scremin-Dias E, Souza ALT (2005) Fitossociologia de um trecho da mata ciliar do rio da Prata, Jardim, MS, Brasil. A. Bot. Bras.. 19 (.3): 597-608. ISSN 0102-3306.

Bianchin JE, Bellé PA (2013) Fitossociologia e estrutura de um fragmento de Floresta Estacional Decidual Aluvial em Santa Maria - RS. R Agro@mbiente On-line, 7 (3): 322330.

Bridgewater S, Ratter JÁ, Ribeiro JF (2004) Biogeographic patterns, b-diversity and dominance in the cerrado biome of Brazil. Biodiversity and Conservation. 13:2295-2318.

Brito ER (2005) Florística e estrutura de fragmentos naturais de florestas inundáveis - Ipucas e identificação de áreas degradadas da fazenda Lago Verde, Lagoa da ConfusãoTO. (Tese de doutorado). Viçosa : UFV.

Brower JE, Zar JH (1984) Field \& laboratory methods for general ecology. W.C. Brown Publishers, Boston.

Carvalho FA (2009) Dinâmica da vegetação arbórea de uma floresta estacional decidual sobre afloramentos calcáreos no Brasil Central. (Tese de doutorado), Universidade de Brasília, Brasília-DF.

Carvalho DA, Oliveira-Filho T, Vilela EA (1996) Flora arbustivo-arbórea de mata ripária do Médio Rio Grande (Conquista, Estado de Minas Gerais). Cerne. 2(2): 048-068.

Carvalho DA, Oliveira Filho AT, Vilela EA, Curi N, Van Den Berg E, Fontes MAL, Botezelli L (2005). Distribuição de espécies arbóreo-arbustivas ao longo de um gradiente de solos e topografia em um trecho de floresta ripária do Rio São Francisco em Três Marias, MG, Brasil. R Bras Bot. 28 (2): 329-345.

Cochrane TT, Sanchez LG, Azevedo L, Porras J A, Garver CL (1985) Land in tropical America. CIAT-EMBRAPACPAC, Cali. 3 vols.

Condit R, Pitman N, Leigh Jr EG, Chave J, Terborgh J, Foster RB, Núñez P, Aguilar S, Valencia R, Villa G, Muller-Landau HC, Losos E, Hubbell, SP (2002) Betadiversity in tropical forest trees. Science. 295, 666-669.

Davidar P, Rajagopal B, Mohandass D, Puyravaud JP, Condit R, Wright SJ, Leigh Jr. EG (2007) The effect of climatic gradients, topographic variation and species traits on the beta diversity of rain forests trees. Globl Ecol Biog. 16(4): 510-518.

Dietzsch L, Rezende AV, Pinto JRR, Silva Pereira BA (2006) Caracterização da flora arbórea de dois fragmentos de mata de galeria do Parque Canjerana, DF. Cerne. 12 ( 3): 201210.

Dufrêne M, Legendre P (1997) Species assemblages and indicator species: the need for a flexible asymmetrical approach. Ecol Monog. 67(3): 345-366.

Felfili J M, Silva Júnior M C (1993) A comparative study of Cerrado (sensu stricto) vegetation in central Brazil. J Trop Ecol. 9(3): 227-289.

Felfili JM, Felfili CM (2001) Diversidade alpha e beta no Cerrado senso stricto da Chapada Pratinha, Brasil. A Bot Bras. 15 (2): 243-254.

Felfili JM, Silva Júnior MC, Sevilha AC, Fagg CW, Walter BMT, Nogueira PE, Rezende AV (2004) Diversity, floristics and structural patterns of Cerrado vegetation in central Brazil. Plant Ecol.175:37-46.

Felfili M F, Carvalho FA, Haidar R F (2005) Manual para o monitoramento de parcelas permanentes nos biomas Cerrado e Pantanal. Brasília: Universidade de Brasília, 55p. 
Felfili JM, Rezende AV, Silva Júnior MC (2007) Biogeografia do Bioma Cerrado: vegetação e solos da Chapada dos Veadeiros. Brasília, Editora Universidade de Brasília/Finatec. 256p.

Ferreira J N (2006) Padrões de estrutura e diversidade da vegetação lenhosa relacionados à heterogeneidade especial de água no solo em Cerrado do Brasil Central. Tese (Doutorado). Universidade de Brasília. Departamento de Pós-Graduação em Ecologia, Brasília - DF.

Ferreira Júnior WGF (2009) Análise de gradientes vegetacionais e pedogeomorfológicos em floresta, Cerrado e campo no Pantanal matogrossense Barão de Melgaço, Mato Grosso. (Tese de doutorado). UFV, Viçosa-MG.

Ferreira FG, Felfili JM, Medeiros MM, Silva Júnior MC, Machado ELM (2010) Fitossociologia de cerrado sentido restrito sobre neossolo flúvico na bacia do rio Paracatu MG. Hering. 4 ( 1)

Finger Z, Finger F A (2015) Fitossociologia em comunidades arbóreas remanescentes de cerrado sensu stricto no Brasil Central. Floresta. 45 (4): $769-780$.

Fonseca MC, Silva Junior MC (2004) Fitossociologia e similaridade florística entre trechos de Cerrado sentido restrito em interflúvio e em vale no Jardim Botânico de Brasília, DF. A Bot Bras. 18:19-29.

Giácomo RG, Carvalho DC, Pereira MG, Souza AB, Gaui MTD (2013) Florística e fitossociologia em áreas de campo sujo e cerrado sensu stricto na estação ecológica de Pirapitinga - MG. Ciên Flor.. 231 ..

Gomes FS, Guedes MLS, Valadão RM, Prates ARS, Costa MAA (2014) Florística e estrutura de um trecho de mata ciliar do rio Carinhanha, Feira da Mata, Bahia, Brasil Biot. 27 (3): 41-55.

Guarino ESG, Walter BMT (2005) Fitossociologia de dois trechos inundáveis de matas de galeria no Distrito Federal, Brasil. A Bot Bras. 19: 431-442.

Haidar RF, Felfili JMF, Pinto JRR, Dias RR, Damasco G, Silva LCR, Fagg CW (2013) Florestas estacionais e áreas de ecótono no estado do Tocantins, Brasil: parâmetros estruturais, classificação das fitofisionomias florestais e subsídios para conservação. A Amaz. 43 (3): 261-290.

Hartshorn GS (1980) Neotropical forest dynamics. Biotrop. 12 (1): 23-30.

Heltshe JF, Forrester N E (1983) Estimating species richness using the jackknife procedure. Biometrics. 39: 1-11.

Hill MO, Gauch HG (1980) Detrend correspondence analysis, an improved ordination technique. Vegetatio, 42:47-58.

IGAM. Instituto Mineiro de Gestão das Águas (2006). Plano diretor de recursos hídricos do Rio Paracatu: resumo executivo. Governo de Minas Gerais. Comitê da Sub-Bacia Hidrográfica do Rio Paracatu. Belo Horizonte: Instituto Mineiro de Gestão das Águas. 384 p.

Kageyama P, Gandara FB (1993) Dinâmica de populações de espécies arbóreas: implicações para o manejo e a conservação. In: Simpósio de Ecossistemas da Costa Brasileira, Anais... São Paulo: ACIESP, 1993. p. 12.

Kent M, Coker P (1992). Vegetation Description and Analysis. Belhaven Press. London.

Köppen W (1936) Das geographische System der Klimate. In:Köppen W, Geiger R (eds) Handbuch der Klimatologie. Gebrüder Borntraeger, Berlin, p 1-44.

Lacerda A, Nordi N, Barbosa FM, Watanabe T (2005) Levantamento florístico do componente arbustivo-arbóreo da vegetação ciliar na bacia do rio Taperoá, PB, Brasil. A Bot Bras. 19 93): 647-656.

Machado RB, Ramos Neto MB, Pereira PGP, Caldas EF, Gonçalves DA, Santos NS, Tabor K, Steininger M (2004)
Estimativas de perda da área do Cerrado brasileiro. Relatório técnico não publicado. Conservação Internacional, Brasília, DF.

Machado RB, Aguiar LMS, Castro AAJF, Nogueira CC, Ramos Neto MB (2008) Caracterização da fauna e da flora do Cerrado, In: Feleiro FG, Farias Neto AL (Ed). Savanas: desafios e estratégias para o equilíbrio entre sociedade, agronegócios e recursos naturais. Planaltina-DF: Embrapa Cerrados. $1198 \mathrm{p}$.

Magurran AE (2004) Measuring biological diversity. Oxford, Blackwell Publishing Company, 256p.

Martins FR (1991) Estrutura de uma floresta mesófila. Editora da UNICAMP, Campinas.

Mccune B, Mefford MJ (1999) PC-ORD - Multivariate analysis of ecological data, Version 4. MjM Software Design, Gleneden Beach.

Martins T, Araujo F; Siqueira K, Ribeiro ACR, Silva-Neto C (2016). Cerrado Forests: Seasonal Forest and cerradão. Agrarian Acad. (3) pp. 1-14.

Mcgeoch MA, Rensburg BJV, Botes B (2002) The verification and application of bioindicators: a case study of dung beetles in a savanna ecosystem. J Appl Ecol. 39 (4): 661-672.

Medeiros MB, Walter BM (2012) Composição e estrutura de comunidades arbóreas de cerrado stricto sensu no norte do Tocantins e sul do Maranhão. R Árvore. 36 (4): 673-683.

Mendonça RC, Felfili JM, Walter BMT, Silva-Júnior MCS, Rezende AV, Filgueiras TS, Nogueira PE, Fagg CW (2008) Flora vascular do Bioma Cerrado - um checklist com 12.356 espécies. In: Sano SM, Almeida SP, Ribeiro JF (org.) Cerrado: Ecologia e Flora Vol. 2. Embrapa Cerrados. Brasília, DF: Embrapa Informação e Tecnologia.

Myers N, Mittermeir RA, Mittermeir CG, FONESCA GAB, KENT J (2000) Biodiversity hotspots for conservation priorities. Nature. 403: 853 - 858 .

Mueller-Dombois D, Ellenberg H (2002) Aims and methods of vegetation ecology. New Jersey: The blackburn press, $547 \mathrm{p}$

Neri AV, Meira-Neto JAA, Silva AF, Martins SV, Batista ML (2007) Análise da estrutura de uma comunidade lenhosa em área de Cerrado sensu stricto no município de Senador Modestino Gonçalves, norte de Minas Gerais, Brasil. R; Árvore. 31(1): 123-134.

Odum EP (2004) Fundamentos de Ecologia. 823p. $6^{\circ}$. ed. Ed. Fundação Calouste Gulbenkian, Lisboa.

Palmer M (2005) Ordination methods for Ecologists. Disponível em: http://ordination.okstate.edu/. (Acesso em: 26/12/2016).

Pereira-Silva EFL, Santos JE, Kageyama PY, Hardt E (2004) Florística e fitossociologia dos estratos arbustivo e arbóreo de um remanescente de cerradão em uma Unidade de Conservação do Estado de São Paulo. R Bras Bot. 27 (3): 533-544.

Pinto SIC, Martins SV, Silva AG, Barros NF, Scross LM (2007) Estrutura do componente arbustivo-arbóreo de dois estádios sucessionais de floresta estacional semidecidual na reserva florestal Mata do Paraíso, Viçosa, MG, Brasil. R Árvore. 31 (5):823-833.

Ratter J A, Bridgewater S, Ribeiro J F (2003) Analysis of the floristic compositionof the Brasilian Cerrado vegetation. III: comparison of the woody vagetation of 376 areas. Edinburgh J Bot. 60 (1): 57-109.

Ribeiro JF, Walter BMT (2008) Fitofisionomias do Bioma Cerrado. In: Sano SM, Almeida SP, Ribeiro JF (Eds.) Cerrado: ecologia e flora. Embrapa Cerrados, Planaltina DF, 2008. 
Rodrigues RR, Leitão Filho HF (2000) Matas ciliares: conservação e recuperação. São Paulo: EDUSP, FAPESP, 2000. 320p.

Rolstad J, Gjerde I, Gundersen VS, Sǽtersdal EM (2002) Use of indicator species to assess forest continuity: a critique. Conser. Biol. 16(1): 253-257.

Santos RM, Vieira FA, Gusmão E, Nunes YRF (2007) Florística e estrutura de uma Floresta Estaional Decidual, no parque municipal da Sapucaia, Montes Claros (MG). Cerne. 13,( 3): 248-256.

Saporetti Jr AW, Meira Neto JAA, Almado RP (2003) Fitossociologia de Cerrado sensu stricto no município de Abaeté-MG. R Árvore. 27 (3): 413-419.

Silva LS, Alves AR, Nunes AKA, Macedo WS, Martins AR (2015) Florística, estrutura e sucessão ecológica de um remanescente de mata ciliar na bacia do rio Gurguéia-PI. Pesquisas Agrárias e Ambientais. Nativa 03 03): 156-164.

Solorzano A, Pinto JRR, Felfili JM, Hay JDV (2012) Perfil florístico e estrutural do componente lenhoso em seis áreas de cerradão ao longo do bioma Cerrado. A Bot Bras. 26: 328-341.

Souza PB, Alves JA, Silva AF, Souza AL (2008) Composição florística da vegetação arbórea de um remanescente de cerradão, Paraopeba, MG. R Árvore. 32 (4): 781-790.
Teixeira MIJG, Araújo ARB, Valeri SB, Rodrihues RR (2004) Florística e fitossociologia de área de cerrados.s. no município de Patrocínio Paulista, nordeste do estado de São Paulo. Bragantia. 63 (1):1-11.

Teixeira M, Pavan AM, Scherer LC, Nicolini G, Freitas EM (2014) Estrutura da comunidade arbórea de um fragmento de mata ciliar do Rio Taquari, Colinas, Rio Grande do Sul. R. Jovens Pesq. 4 (1): 19-31.

Ter Braak CJF, Smilauer P (2002) CANOCO Reference manual and Cano Draw for Windows User's guide: Software for Canonical Community Ordination (version 4.5).Microcomputer Power (Ithaca, NY, USA), $500 \mathrm{pp}$.

Ter Steege $\mathrm{H}$ et al. (2013) Hyperdominance in the Amazonian tree flora. Science. 342:6156.

Tuomisto H, Ruokolainen K, Yli-Halla M (2003) Dispersal, environment, and floristic variation of westerm Amazoniam forest. Science. 299: 241-244.

Walter BMT, Durigan G, Munhoz CBR, Ribeiro J FR (2015) Fitofisionomias do Cerrado: classificação, métodos e amostragens fitossociológicas. In: Eisenlohr PV, Felfili JM, Melo M MRF, Andrade LA, Meira Neto JAA (Org) Fitossociologia no Brasil: métodos e estudos de casos. Volume II. Viçosa, MG: Ed. UFV, 474p.

Zar JH (1996) Biostatistical analysis. 3a ed. Prentice Hall, New Jersey, 1996. 